TAJ December 2011; Volume 24 Number 2

Published on 2016

\title{
A Comparative Study Between Palonosetron and Granisetron to Prevent Postoperative Nausea and Vomiting after Laparoscopic Cholecystectomy
}

\author{
S M A Taher ${ }^{1}$, Jamil Raihan ${ }^{1}$, M Abu Zahid ${ }^{1}$, A K Azad ${ }^{1}$, M I Alam ${ }^{2}$, F Deeba $^{3}$
}

\begin{abstract}
Post operative nausea and vomiting is a frequent complication following general anaesthesia and surgery. There is frequently the case of great distress to patient and it is often the worst memory, uncomfortable of their hospital stay. Prolonged post operative nausea and vomiting may cause unexpected physical, metabolic, psychological and economic effects on the patients which slow down their recovery and reduce their confidence in future surgery and anaesthesia.

In the present study, we have the incidence of post operative nausea and vomiting in sixty (60) patients undergoing for elective procedure under general anaesthesia. The patients were randomly divided into two groups (group- P, group- G) of thirty (30) patients each.The Patients of group ' $P$ ' were received intravenous Inj. Palonosetron $75 \mu \mathrm{g}$ and group ' $G$ ' received intravenous Inj. granisetron $2.5 \mathrm{mg}(2.5 \mathrm{ml})$ bolus over 30 second just before peritoneal closure. Both group received a standard general anaesthesia. Postoperative analgesia was provided with per rectal diclofenac suppository $(50 \mathrm{mg})$ and Inj. Ketorolac Tromethamine $30 \mathrm{mg} 8 \mathrm{hourly}$. In the recovery, postoperative room occurrence of nausea and vomiting was assessed for 24 hours. The incidence of post operative nausea and vomiting was reduced in both groups significantly but comparison between these two groups for prevention of PONV(postoperative nausea and vomiting) following elective laparoscopic cholecystectomy surgery is similar. Palonosetron has more prolonged effect than granisetron. There was no evidence of any adverse side effects and whole of the post operative period was smooth.
\end{abstract}

TAJ 2011; 24(2): 118-123

\section{Introduction}

Postoperative nausea and vomiting (PONV) are distressing symptoms that commonly occurs after laparoscopy surgery performed under general anaesthesia ${ }^{1}$.Vomiting may cause dehydration, electrolyte imbalance, disruption of surgical repair and increase perception of pain ${ }^{2}$.

A number of pharmacological agent antihistamine, butyrophenone, dopamine receptor antagonist have been tried for the prevention and treatment of PONV but undesirable adverse effects such as excessive sedation, hypertension, dry mouth, dysphorea, hallucination and extra pyramidal symptoms have been noted ${ }^{3}$. 5-HT(5-hydroxy tryptamine) receptor antagonists are devoid of such side effects and highly effective in prevention and treatment of PONV. Granisetron is a highly selective and potent $5-\mathrm{HT}_{3}$ receptor antagonist ${ }^{4}$. It acts specifically at $5-\mathrm{HT}_{3}$ receptor on the vagal nerve of the gut. Granisetron produces irreversible block of the $5-\mathrm{HT}_{3}$ receptors and it may account for the long duration of this drug ${ }^{5,6}$. Palonosetron is $5-\mathrm{HT}_{3}$ receptor antagonist used for preventing

${ }^{1}$ Assistant Professor, Department of Anesthesiology \& Intensive Care Unit, Rajshahi Medical College, Rajshahi.

2 Professor \& Head, Department of Anesthesiology \& Intensive Care Unit, Rajshahi Medical College, Rajshahi.

${ }^{3}$ Lady Assistant Surgeon, FWVTI, MCH Unit, Rajshahi, Rajshahi. 
PONV and chemotherapy induced nausea and vomiting.This unique $5-\mathrm{HT}_{3}$ receptor antagonist has a greater binding affinity and longer half life than older $5 \mathrm{HT}_{3}$ antagonist like ondensetron.

Recent receptor binding studies that palonosetron is further differentiated from other $5-\mathrm{HT}_{3}$ by interacting with 5-HT reception an allosteric, positive cooperative manner at site different from those that bind with ondensetron and granisetron ${ }^{7}$. In addition, this sort of receptor interaction may be associated with long lasting effects on ligand binding and functional respond to serotonin ${ }^{\mathbf{8}}$.

Postoperative period is associate with variable incidence of nausea and vomiting depending on surgery; the type of anaesthetic agent used (dose, inhalation drugs, opioids) smoking habit etc ${ }^{9}$. 5$\mathrm{HT}_{3}$ receptor stimulation is the primary event in the initiation of vomiting reflex ${ }^{\mathbf{1 0}}$.

Anaesthetics agent initiate the vomiting reflex by stimulating the centre $5-\mathrm{HT}_{3}$ receptor of the CTZ and also by releasing serotonin from the enterochromaffin cells of small intestine and subsequent stimulation of $5-\mathrm{HT}_{3}$ receptor on the nerve afferent fiber ${ }^{3}$. The incidence of PONV after laparoscopic surgery is high[40-75\%].The etiology of PONV after laparoscopy surgery is complex and is dependent on a variety of factors including age, obesity, surgical procedure, anaesthetic technique and postoperative pain ${ }^{\mathbf{1 1}}$.

In this study, however both were comparable with respect to patient demographic type and duration of surgery and anaesthesia and analgesics used postoperative pain ${ }^{\mathbf{1 1}}$. Granisetron is effective for the treatment of emesis induced by cancer theraphy ${ }^{\mathbf{1 2}}$. The precise mechanism of granisetron for prevention remain unclear, but it has been suggested that granisetron may acts on sites containing $5-\mathrm{HT}_{3}$ receptors with demonstrated antiemetic effect ${ }^{13}$.The effective dose of granisetron is $40-80 \mu g k g-1$ for the treatment of cancer chemotherapy induced nausea and vomiting $^{14}$. The dose of palonosetron to be used for the prevention of PONV is no established but not extrapolted from the dose used in the clinical trials ${ }^{15,16}$.

\section{Methods}

This study was carried out in the department anaesthesiology of Rajshahi medical college hospital April 2012 to october 2012.It is prospective randomized double blind study.

All patients age 18- 45 years ASA Physical status 1 and 11,normotensive,uncomplicated patient, admitted in Department of surgery of Rajshahi Medical college hospital in the study period for elective laparoscopic cholecystectomy was taken as study population. Exclusion criteria ASA status $111,1 \mathrm{~V}, \mathrm{~V}$, kwon allergy, Body mass index(BMI) greater than 30. Sixty patients undergoing elective laparoscopic cholecystctomy were randomly allocated one of the two group containing 30 patients each. Patients were randomly allocated into two groups ( $n=30$ each) to receive one of the following regimens; palonosetron $75 \mu \mathrm{g}$ in $2.5 \mathrm{ml}$ ( $0.9 \%$ saline was added to the desire volume) [group P] or granisetron $2.5 \mathrm{mg}$ in $2.5 \mathrm{ml}$ [group G]. All patients were kept fasting after midnight and received midazolam $7.5 \mathrm{mg}$ orally as premedication. On the operation table routine monitoring (ECG, pulse oximetry, NIBP) were started and baseline vital parameters like heart rate (HR), blood pressure (systolic, diastolic, and mean) and arterial oxygen saturation $\left(\mathrm{SpO}_{2}\right)$ were recorded. In the preoperative period, the procedure of the work explained to the patients and informed consent was explained to the patient. In the pre operative period patients were also inquired about motion sickness, history of previous anaesthesia, and post operative emesis.

On arrival of the patients in the operation room I/V line was checked and secured and pulse rate, blood pressure and respiratory rate was rechecked and recorded. Oxygen saturation was measure by pulse oxymeter. The patients were preoxygenated for three minutes and induction was with Inj.Fentanyl $1 \mu \mathrm{g} / \mathrm{kg}$, inj.Thiopentone $5 \mathrm{mg} / \mathrm{kg}$, tracheal intubation was facilitated by Inj. Suxamethonium $1.5 \mathrm{mg} / \mathrm{kg}$ and general anaesthesia was maintain by halothane $0.5 \%, \mathrm{~N}_{2} \mathrm{O}$ $60 \%$, with $\mathrm{O}_{2} 40 \%$. Nondepolarizing muscle relaxant Inj.Vecuronium $0.1 \mathrm{mg} / \mathrm{kg}$ was given. Intraoperative proper hydration was maintain with Hartmann`s solution. Just before peritoneal closure 
Inj.palonosetron $75 \mu \mathrm{g}$ in group 'P' patients and Inj. granisetron $2.5 \mathrm{mg}$ group' $G$ ' patients was given. At the end operation, the patient was reversed accordingly with Inj.Neostigmine 0.05 $\mathrm{mg} / \mathrm{kg}$ plus Inj. Atropine $0-.02 \mathrm{mg} / \mathrm{kg}$ and recovery was smooth and uneventful.

Postoperative follow up was carried out in the recovery and postoperative ward by investigator. In the recovery and post operative ward analgesia was provided with per rectal diclofenac suppository (50 mg) and Inj. Ketorolac Tromethamine $30 \mathrm{mg} \quad 8$ hourly $\mathrm{I} / \mathrm{M}$ on complaining pain and repeated in all patients when necessary. Presence of nausea and vomiting patients were interviewed at one hourly over the first 3 hours study period was begin upon entry to the recovery room and 24 hours postoperative period. Pulse, blood pressure, SpO2 monitor upto 24 hour. The number and time of emetic episodes and the number and time of rescue antiemetic treatment was recorded. The rescues protocol constituted of Inj. palonosetron / granisetron injection once. Patients were carefully observed for any adverse effect like sedation, Headache, Dizziness, drowsiness, flushing of any extrapyramidal symptom.

\section{Results}

Sixty patients of two two group received palonosetron and ondensetron.There were no statistical difference between between two groups by age, body weight and duration of operation (Table no 1). Postoperative complete response group-G 25(83.33\%) and group-P 27(90\%), nausea 5(16.66\%) and 2(6.66\%), vomiting 3(10\%) and 2(6.6\%) respectively during 0-3 hours. During 03-24 hours, nausea and vomiting 4(13.3\%), $3(10 \%)$ and 2(6.6\%), 2(6.6\%) respectively. In addition, 0-24 hours headache, dizziness and drowsiness also occurs.

Table-1: The demographic data of age, weight and duration of surgery of different groups.

\begin{tabular}{llll}
\hline Groups & Age & Weight & Duration \\
\hline Group -P & $35.36 \pm .896$ & $51.42 \pm 8.22$ & $69.53 \pm 1.95$ \\
Group -G & $37.50 \pm 1.22$ & $52.24 \pm 7.36$ & $70.06 \pm 1.84$ \\
p-value & 0.513 & 0.573 & 0.853 \\
\hline
\end{tabular}

Table- 11: Post operative nausea and vomiting

\begin{tabular}{llll}
\hline $\begin{array}{l}\text { Postoperative } \\
\text { period(hr) }\end{array}$ & $\begin{array}{l}\text { Granisetron } \\
(\mathrm{n}=30)\end{array}$ & $\begin{array}{l}\text { Palonosetron } \\
(\mathrm{n}=30)\end{array}$ & $\begin{array}{l}\text { P- } \\
\text { Value }\end{array}$ \\
\hline $\mathbf{0 - 3} \mathbf{h r}$ & & & \\
$\begin{array}{l}\text { Complete } \\
\text { Response }\end{array}$ & 25(83.33\%) & $27(90 \%)$ & 0.65 \\
Nausea & $5(16.66 \%)$ & $2(6.6 \%)$ & 0.68 \\
Vomiting & $3(10 \%)$ & $2(6.6 \%)$ & 0.42 \\
Rescue drug & 0 & 0 & 1 \\
3-24 hr & & & \\
Complete & $24(80 \%)$ & $27(90 \%)$ & 0.58 \\
Response & & & \\
Nausea & $4(13.3 \%)$ & $2(6.6 \%)$ & 0.72 \\
Vomiting & $3(10 \%)$ & $2(6.6 \%)$ & 0.68 \\
Rescue drug & 0 & 0 & 1 \\
\hline
\end{tabular}

Table - 111: Post operative adverse effects

\begin{tabular}{llll}
\hline $\begin{array}{l}\text { Postoperative } \\
\text { period(hr) }\end{array}$ & $\begin{array}{l}\text { Granisetron } \\
(\mathrm{n}=30)\end{array}$ & $\begin{array}{l}\text { Palonosetron } \\
(\mathrm{n}=30)\end{array}$ & $\begin{array}{l}\mathrm{P} \text { - } \\
\text { value }\end{array}$ \\
\hline $\mathbf{0 - 3}$ hr & & & \\
Headache & $3(10 \%)$ & $2(6.66 \%)$ & 0.68 \\
$\begin{array}{l}\text { Dizziness } \\
\text { Drowsiness }\end{array}$ & $\begin{array}{l}\text { (2(13.3\%) } \\
\text { 3-24 hr }\end{array}$ & $\begin{array}{l}2(6.6 \%) \\
1(3.3 \%)\end{array}$ & 0.72 \\
Headache & $2(6.6 \%)$ & $2(6.6 \%)$ & 1 \\
$\begin{array}{l}\text { Dizziness } \\
\text { Drowsiness }\end{array}$ & 3(10\%) & $2(6.6 \%)$ & 0.63 \\
$\mathbf{2 4 - 4 8 ~ h r}$ & $2(6.6 \%)$ & $1(3.3 \%)$ & 0.65 \\
\hline
\end{tabular}

\section{Discussion}

Postoperative period is associated with variable incidence of nausea and vomiting depending on the duration of surgery, the type of anaesthetic agents used (dose, inhalational drugs, opioids) smoking habit etc ${ }^{\mathbf{9}}$. $5-\mathrm{HT}_{3}$ receptor stimulation is the primary event in the initiation of vomiting reflex ${ }^{10}$. These receptors are situated on the nerve terminal of the vagus nerve in the periphery and centrally on the chemoreceptor trigger zone (CTZ) of the area postrema ${ }^{3}$. Anaesthetic agents initiate the vomiting reflex by stimulating the central 5$\mathrm{HT}_{3}$ receptors on the CTZ and also by releasing serotonin from the enterochromaffin cells of the small intestine and subsequent stimulation of 5$\mathrm{HT}_{3}$ receptors on the vagus nerve afferent fibres ${ }^{3}$ The incidence of PONV after laparoscopic surgery is high (40-75\%). The etiology of PONV after laparoscopic surgery is complex and dependent on a variety of factors including age, obesity, a history of previous PONV, surgical 
procedure, anaesthetic technique and post operative pain ${ }^{11}$. In this study, however, both the groups were comparable with respect to patient demographics, types and duration of surgery and anaesthesia and analgesics used postoperatively. Therefore the difference in a complete response (no PONV, no rescue medication) between the groups can be attributed to the study drug.

In our study incidence of nausea and vomiting in group-P (those received inj. Palonosetron $75 \mu \mathrm{g}$ ) is $6.6 \%$ and in group- $G$ (those received inj. Granisetron $2.5 \mathrm{mg}$ ) is $16.6 \%$ and $10 \%$ respectively in the period $0-3$ hour. In the period 3-24 hours nausea and vomiting group-P is $6.6 \%$ and in group-G is $13.3 \%$ and $10 \%$ respectively.

Our study demonstrate that the antiemetic efficacy of Group- P (palonosetron) is similar to that of Group-G (granisetron) for preventing PONV during first 24 hours (0-24 hours) after laparoscopic cholecystectomy and that Group-P (palonosetron) is more effective than granisetron for getting a complete response (no PONV, no rescue medication) for 24-48 hours. This suggests that palonosetron has an antiemetic effect which lasts longer than granisetron. The exact reason for the difference in effectiveness between granisetron and palonosetron is not known but may be related to the half lives (granisetron 8-9 hours versus palonosetron 40 hours) and/ or the binding affinities of $5-\mathrm{HT}_{3}$ receptor antagonists (palonoseptron interacts with $5-\mathrm{HT}_{3}$ receptors in an allosteric, positive cooperative manner at sites different from that bind with granisetron) ${ }^{7,8}$. We did not include a control group receiving placebo in this study.

Adverse effects with a single therapeutic dose of granisetron or palonosetron were not clinically

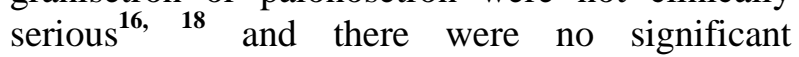
differences in the incidence of headache, dizziness and drowsiness between the groups. Thus both palonosetron and granisetron are devoid of clinically important side effects.

The aggravating factors for PONV in general anaesthesia are anaesthetics agents, distention by gas $\left(\mathrm{CO}_{2}\right)$, per and postoperative use of narcotics. But in our study the possible aggravating factor are female patient hormonal changes, general anaesthesia and vagal irritation.

Regarding hemodynamic changes (pulse, blood pressure) $\mathrm{SpO}_{2}$, respiratory changes, during operation and 24 hours postoperative period in some period significant changes were observed $(p<0.05)$ but in other period no significant changes occur. No other adverse effect like headache, constipation and flushing during operation and 24 hours postoperative period were observed in this study.

Pain as well as commonly used analgesic pethedine may cause nausea and vomiting. For this reason postoperative control of pain we used ketorolac tromethamine and diclofenac as required instead of pethedine. We chose single dose I/V because it is more easily to give one dose during operation. The study confirmed the previous study regarding the safety of the patient as side effects were mild.

However further work is required to compare between palonosetron and granisetron about their efficacy for prevention of PONV in laparoscopic cholecystectomy under general anaesthesia. We did not include a control group receiving placebo in our study. Aspinall and Goldman ${ }^{19}$ have suggested that if active drugs are available, placebo controlled trials may be unethical because PONV are very much distressing after laparoscopic surgery ${ }^{17 .}$

Postoperative follow up was carried out in the recovery and postoperative ward by investigator. Adverse effects with a single therapeutic dose of granisetron or palonosetron were not clinically serious ${ }^{\mathbf{1 6 , 1 8}}$ and there were no significant difference of headache, dizziness, and drowsiness between the groups. Thus both palonosetron and granisetron are devoid of clinically important side effects.

In another study most of the incidence of PONV occur with first two hours after surgery in two groups but in rest of the period no nausea and vomiting occur which is similar with the study of Dr. Bridges ${ }^{21 .}$ It has some dissimilarity with the study of Dr.Naguib $\mathrm{M}^{22}$ and Dr.Dipasri Bhattacharya $^{23}$. Most of the operations in previous 
study were done under general anaesthesia. The aggravating factors for PONV in general anaesthesia are anaesthetics agents, distention by gas, per and post operative use of narcotics. But in our study the possible aggravating factor are general anaesthesia, vagal irritation and distention by gas. Postoperative analgesia was provided with per rectal diclofenac suppository (50mg) 8 hourly. In the recovery room occurrence of nausea vomiting was assessed for 24 hours.

The incidence of a complete response no PONV, no rescue medication during $0-3$ hour in the postoperative period was $90 \%$ with palonosetron and 83.33\% with Granisetron. During 3-24 hour, the incidence was $90 \%$ and $80 \%$ respectively. In postoperative period within $0-3$ hour the incidence of nausea and vomiting were observed in group ' $\mathrm{P}$ ' two cases 2 (6.6\%) out of 30 and in group ' $\mathrm{G}$ ' three cases $3(10 \%)$ out of 30 . So antiemetics were given in those patients. No significant difference was observed between Group 'P' and Group ' $G$ '

\section{Conclusion}

It is concluded that both palonosetron and granisetron have similar antiemetic efficacy but dose of palonosetron is much more less than granisetron and less frequent dose is required and also sufficiently longer acting than granisetron. There was no evidence of any adverse side effects and whole of the period was smooth. In conclusion prophylactic therapy with palonosetron is more effective than prophylactic therapy with granisetron for the long term prevention of PONV after laparoscopic cholecystecomy.

\section{References}

1. Madej T,Simson K. Comparison of the use of domperidone, droperidol and metoclopramide in the prevention of nausea and vomiting following gynecologyical surgery. $\mathrm{Br}$ Ja Anaesth 1986; 58: 879-83.

2. Jellish WS, Leonetti J P, Sawicki K,et el. Morphine/Ondansetron PCA for post operative pain ,nausea and vomiting after skull base Surgery,Otolaryngol Head Neck surg 2006; 135: 175-81.

3. Watcha MF, White PF, post operative pain ,nausea and vomiting: its etiology, treatment and prevention. Anaesthesiology 1992; 77: 162-84.
4. Blower PR. The role of specific $5-\mathrm{HT}_{3}$ receptor antagonistin the control of cytostatic drug induced emesis.Euro J cancer 1990; 26(suppl.1) s8-s11.

5. Newberry NR, Watkins CL, Sprosen TS, Black burn TP, Grahame Smith DG, Lieslie RA . BRL 46470 potently antagonizes neural responses activated by $5-\mathrm{HT}_{3}$ receptors. Neuropharmacology 1993 ;32: 729-735.

6. Elliott $P$, Seemungal BM, willis DI. Antagonism of the effects of $5-\mathrm{HT}_{3}$ on the rabbit

7. isolated vagus nerve by RBL 43694 and metoclorpramide. Naunyn- Schmied activitives of phamacology 199o; 341:503 -09.

8. Rajos C Statis M, Thamas A, Massuda E, Alt J,Zhang J, RobensteinE, Sebastianis S, Canloriggi $\mathrm{S}$, Synder SH, Sluusher Mb,. Palonosetron exibits unique molecular interactions with $5-\mathrm{HT}_{3}$ receptor. Anesth Anal 2008;107: 469-78.

9. Gralla R, Lichinitser M, Vander Vegt S, Sleeboom $\mathrm{nH}$, Mezger J, Peschel C, Tonini G, Libianca R, Macciocchi A, Anapro M, Palonosetron improves prevention of chemotherapy induced nausea and vomiting following moderately emetogenic chemotherapy: results of adouble- blind randomised phase 3 trial comparing single dose of palonosetron with ondensetron. Ann Oncol 2003; 14: 1570-7.

10. Lerman J, Surgical and patient factors involved in postoperative nausea and vomiting $\mathrm{Br} \mathrm{J}$ Anaesth 1992; 69: 245-325.

11. Bunce KT, Tyers MB. The role of $5-\mathrm{HT}_{3}$ in postoperative nausea and vomiting. $\mathrm{Br} \mathrm{J}$ Anaesth 1992; 69(supply):S 60-S62.

12. R Janknegt et al. Clinical efficacy o antiemetics following surgery. anaesthesia 1999; 54: 1059-68.

13. Bermudez J, Boyle Ea, Minter WD, Sanger GL. The antiemetic potential of the 5 -HT3 receptor antagonist BR 43694. Br J Cancer 1988; 58: 64450.

14. Camichel J, Cantwell BMJ,Edwards CM,ct al. A pharmokinetics study of granisetron (BRI 43694),a selective 5-HT3 receptor antagonist: correction of antiemetic response. Cancer Chemother Pharmacol 1989; 24:45-9.

15. Furue $\mathrm{H}$, Oota $\mathrm{K}$, Taaguchi T,Niitani H. Clinical evaluation of granisetron against nausea and vomiting induced by anticancer drugs: Optional dose of finding study. J Clin Ther Med 1990;16: 4961.

16. Candiotti KA, Kovac AL, Melson TI, Clerici G, Gan $\mathrm{TJ}$. A randomized double-blind study to evaluate the efficacy and safety of three different doses of 
palonosetron versus placebo for preventing postoperative nausea and vomiting. Anesth Analg 2008; 107: 445-51

17. Kovac AL, Eberhat L,. Kotarski J, Clerici G, Apfel C. A randomized double blind study to evaluate the efficacy and safety of three different doses of palonosetron versus placebo for preventing post operative nausea and vomiting

18. over a 72 hour period. Anesth Analg 2008;107: 439-6.

19. Aspinall RL, Goodman NW. Denial of effective treatment and poor quality of clinical information in placebo controlled trials of ondensetron for postoperative nausea and vomiting: a review of published trials. BMJ. 1995; 311:844-6.[PMC free article] [PubMed].

20. Yaker YE, Mactavish D. granisetron: an update of its therapeutic use in nausea and vomiting induced by antineoplastic therapy. Drugs.1994; 48:76193.[pubMed]

21. Paxton DL, Mekay CA, Mirakin KR, prevention of nausea and vomiting after day case gynaecolo'gical Laparoscopy,Anaesthesia 1995; 50:403-406.
22. Craft TM, uptom PM.Anaesthesia clinical aspects, $3^{\text {rd }}$ edition 2001; 279-281.

23. John D. Bridge, BS (pharma), Cindy B. Nettle, Pharm D, vijaya.T. Dugirrala MD, Katie J. Suda, Pharma D, Low dose granisetron for prevention of post operative nausea and vomiting, The journal of Applied Research, vol. no. 3,2006.

24. Naguib $M$, Bakry AK el, Khoshim MH, Channa AB,Gammal Me el, Gammal K el, Elhattab YS, Attia $M$, Jaroudi $R$ and Saddique $A$. Prophylactic antiemetic therapy with ondansetron, tropisetron, granisetron and metoclopramide in patient undergoing laparoscopic cholecystectomy: arandomized, double- blind comparison with placebo. Department of anaesthesia, Surgery,Faculty of Medicine ,King Khaliud University Hospital, Riyad, Saudi Arabia.

25. Dr. Dipasri Bhattacharya, Dr. Arnab Banergee, Comparison of Ondansetron and granisetron for prevention of nausea and vomiting following day care Gynaecological Laparoscopy. Indian J. Anaesthe. 2003; 47(4): 279-282. 